\title{
A Case Study on OTC Market - Choice to Enter?
}

\author{
Nidhi Chowdhry \\ Ansal University and Akshay Dhar, PGDM - Marketing, IMT Ghaziabad
}

Copyright (C) 2015 Horizon Research Publishing All rights reserved.

\begin{abstract}
The Indian Pharmaceutical Industry is one of the emerging markets which currently has a significant growth potential. Pharmaceutical companies are changing their marketing strategies according to the new competitive business environment. This case study focuses on the recently launched Over The Counter (OTC) division of a Pharmaceutical company. The case highlights various market conditions prevailing at present with respect to pharmaceutical OTC market segments in Analgesics, Sun Care and Digestive remedies. It provides brand wise share analysis and competitors' market share analysis of all three segments to help reach solution for the business problem of choice highlighted in the case.
\end{abstract}

Keywords OTC Marketing, Marketing Strategies, Pharmaceutical Industry, Branding Decisions for Promotions, Market Segmentation of Brands

\section{Introduction}

As Prashant sipped over his early morning coffee, he started recollecting yesterday's events. The chat he had with his boss, Rajeev Shukla, the Indian Business Head (Generics division) had particularly unsettled him. Prashant Sharma was being made the Marketing Director of the newly launched Over The Counter (OTC) division of Elimbi Pharmaceuticals. Prashant mused over the options he had and the decision he had to make in order to justify Rajeev's trust in him. Prashant had been entrusted with ensuring a successful opening for the OTC division of Elimbi. He has been given an option of 3 segments from which to choose from as his means of entry into the OTC market - Analgesics, Digestive remedies and Sun Care.

\section{Background: Elimbi Pharmaceuticals}

Elimbi Pharmaceuticals is a US \$2 billion Indian company headquartered in Gurgaon. It was founded in 1992 by Nikhil Surogi who had done his B.Pharm from NIPER, Mohali and had previously worked in the Indian Drugs and Pharmaceuticals Limited of Hyderabad, India. Elimbi is a vertically integrated company that develops, manufactures and markets Generic, Branded Generic and Active Pharmaceutical Ingredients (APIs). It has a portfolio of medicines and intermediaries that include tablets, capsules, ointments, creams and liquids. The divisions in which its therapies exist include Dermatology, Urology, Nutraceuticals, Cardiovascular, Oncology and Dental. Oncology was the most profitable division for the company, contributing to about $19.8 \%$ of its overall sales.

\section{Analysis of the OTC Scenario in India}

The OTC segment in India is not identified separately. Instead, anything that does not fall in the prescription drugs category is classified as being Over The Counter. The growth of the Indian OTC market has outpaced the other OTC markets in the world. Currently, the Indian OTC market ranks $11^{\text {th }}$ in terms of market size globally. The Indian OTC market is extremely competitive at present. The pharmaceutical companies are fighting it out with the leading FMCG companies for a share of the consumer's wallet. Awareness is a major problem when dealing with OTC products in rural and semi-urban India and consumers prefer to self-medicate themselves using herbal options. In the extreme condition of a serious illness, a doctor is consulted. A paradigm shift has been observed in the lifestyle of the urban consumer though. Buoyed by the zeal to remain fit and active, the urban consumer has shifted to the adoption of vitamins and dietary supplements. As a result, sports nutrition is expected to be the highest driver of value over the next five years. Long working hours, sedentary jobs and fast-paced lives have further accentuated the usage of supplements. Modern retailing of OTC products is still in its infancy and its presence is limited to urban areas. Chemists and pharmacists lead the OTC retail channel with their penetration being extremely high, especially in tier II and III cities and in rural areas.

\section{The Business Problem}

The OTC division was about to be launched by the company in the next two months. Till now the company engaged only in prescription drugs. Prashant had been given 
an option of three market segments to choose from:

- Analgesics

- Digestive remedies

- Sun Care

Rajeev Shukla had given a two week time frame for Prashant to discuss with his newly formed 5 member OTC team and come up with the most profitable option out of the three given. Rajeev had already started to grow tense given the short time frame in which he had to come up with a decision. Also, a lot of major competitors had already made inroads in all the three probable segments in the OTC market. A decision had to be reached based upon sound reasoning market potential, market capacity, the number of major competitors and the ability to create a niche for themselves in the market space. Prashant goes through the various reports compiled by his team on the three segments.

Table 1. Brand Shares of Analgesics: \% Value 2010-2013

\begin{tabular}{|c|c|c|c|c|c|}
\hline $\begin{array}{c}\text { \% retail value } \\
\text { rsp }\end{array}$ & Company & 2010 & 2011 & 2012 & 2013 \\
\hline Zandu & Emami Ltd & 11.5 & 12.4 & 12.9 & 13.4 \\
\hline Iodex & $\begin{array}{c}\text { GlaxoSmithKline } \\
\text { Consumer Healthcare Ltd }\end{array}$ & 11.3 & 11.1 & 10.7 & 10.9 \\
\hline Volini & Ranbaxy Laboratories Ltd & 5.9 & 6.8 & 8.0 & 9.0 \\
\hline Moov & $\begin{array}{c}\text { Paras Pharmaceuticals } \\
\text { Ltd }\end{array}$ & 7.6 & 8.2 & 8.3 & 8.7 \\
\hline Amrutanjan & $\begin{array}{c}\text { Amrutanjan Health Care } \\
\text { Ltd }\end{array}$ & 7.1 & 7.3 & 7.6 & 7.7 \\
\hline Emami & Emami Ltd & 4.9 & 5.3 & 5.5 & 5.7 \\
\hline Crocin & $\begin{array}{c}\text { GlaxoSmithKline } \\
\text { Consumer Healthcare Ltd }\end{array}$ & 4.7 & 4.7 & 4.7 & 4.7 \\
\hline Calpol & $\begin{array}{c}\text { GlaxoSmithKline } \\
\text { Pharmaceuticals Ltd }\end{array}$ & 4.3 & 4.2 & 4.1 & 4.2 \\
\hline Disprin & $\begin{array}{c}\text { Reckitt Benckiser (India) } \\
\text { Ltd }\end{array}$ & 3.4 & 3.3 & 3.3 & 3.2 \\
\hline Tiger Balm & Elder Health Care Ltd & 2.7 & 2.9 & 3.0 & 3.2 \\
\hline
\end{tabular}

Source: Euromonitor International from official statistics, trade associations, trade press, company research, store checks, trade interviews, trade sources

\section{Analgesics:}

The analgesics market witnessed a growth of $10 \%$ in 2013 to reach a value of INR 17 billion. Topical analgesics witnessed a growth rate of $12 \%$ in terms of value in 2013 and accounted for $72 \%$ of the total value sales of analgesics ${ }^{1}$. It continues to drive growth for this category owing to the easy application and availability of products which makes it a preferred OTC option for body pains and injuries. Another driver for the growth of topical analgesics in India is the habit of consumers to first cure aches and pains on their own before going to see a doctor. The Indian consumer prefers the traditional herbal products, which is evident in the strong market presence and success of brands like Zandu, Iodex and Amrutanjan. The trust in these brands and the well-established presence has ensured that they continue to

\footnotetext{
${ }^{1}$ http://www.research and markets.com/reports/ Analyzing Consumer's Perception of OTC drugs in India
}

lead the Indian market. A rising trend among analgesics is the desire of companies to realize growth using marketing and promotional activities.

The market in India is dominated by Emami with the bestselling brand being Zandu. The company continues to lead the Indian market in 2013 with a 22\% share. GlaxoSmithKline Consumer Healthcare limited stands at second place with a $16 \%$ share owing to its flagship brands Iodex, Calpol and Crocin. A reason for the success of Zandu and Iodex was the preference of Indian consumers towards herbal and traditional balms. While the topical analgesics are promoted majorly through television commercials, companies continue to force growth in the systemic analgesics category through a mix of television commercials, in-store and print media promotion. Non-herbal brands such as Volini are also expected to witness large growth as some of these standard brands tend to be more effective than herbal ones. The problem facing the non-herbal brands is the relatively higher price at which they are offered to the consumers as opposed to the herbal brands.

Table 2. Company Shares of Analgesics: \% Value 2009-2013

\begin{tabular}{|c|c|c|c|c|c|}
\hline \% retail value rsp & 2009 & 2010 & 2011 & 2012 & 2013 \\
\hline Emami Ltd & 16.7 & 19.0 & 20.4 & 21.0 & 21.7 \\
\hline $\begin{array}{c}\text { GlaxoSmithKline Consumer } \\
\text { Healthcare Ltd }\end{array}$ & 16.0 & 16.0 & 15.8 & 15.4 & 15.6 \\
\hline Ranbaxy Laboratories Ltd & 5.2 & 5.9 & 6.8 & 8.0 & 9.0 \\
\hline Paras Pharmaceuticals Ltd & 6.6 & 7.6 & 8.2 & 8.3 & 8.7 \\
\hline Amrutanjan Health Care Ltd & 7.1 & 7.2 & 7.4 & 7.7 & 7.8 \\
\hline $\begin{array}{c}\text { GlaxoSmithKline Pharmaceuticals } \\
\text { Ltd }\end{array}$ & 4.4 & 4.3 & 4.2 & 4.1 & 4.2 \\
\hline Reckitt Benckiser (India) Ltd & 3.5 & 3.6 & 3.5 & 3.4 & 3.4 \\
\hline
\end{tabular}

Source: Euromonitor International from official statistics, trade associations, trade press, company research, store checks, trade interviews, trade sources

Table 3. Forecast Sales of Analgesics by Category: \% Value Growth 2013-2018

\begin{tabular}{|c|c|c|}
\hline \% constant value growth & 2013-18 CAGR & 2013/18 TOTAL \\
\hline Systemic Analgesics & 2.1 & 10.9 \\
\hline - Adult Analgesics & 2.1 & 10.9 \\
\hline - Paediatric Analgesics & - & - \\
\hline Topical Analgesics/Anaesthetic & 2.6 & 13.8 \\
\hline Analgesics & 2.5 & 13.0 \\
\hline
\end{tabular}

Source: Euromonitor International from trade associations, trade press, company research, trade interviews, trade sources

Analgesics are expected to grow at a steady rate in the coming years mainly due to the lack of time among consumers, especially those residing in urban areas. A paucity of time will eventually lead to the need for a quick remedy for joint, body and muscle pains. The major challenge for the systemic analgesics would be the removal of harmful side effects which would lead to a greater 
acceptance of those drugs. A greater knowledge about the side effects of medicines due to the spread of internet has lead to the consumers keeping away from systemic analgesics. Thus, the companies looking to enter would most likely look for a herbal and topical way of entering this high growth segment.

\section{Digestive remedies:}

This is an INR 12 billion segment which grew at a rate of $8 \%$ in 2013. Dabur continued its leadership with a 34\% market share in the Indian market in terms of value. Its flagship brands Hajmola and Pudin Hara continued to dominate the digestives market. Due to the herbal formulation of Dabur's remedies, its products were widely accepted and preferred by the consumers. The major multinational companies which have a major share in the Indian market are GlaxoSmithKline, Abbott and Pfizer. The private label market continues to struggle as consumers' preferred branded medicine and there is an additional premium attached to traditional products ${ }^{2}$.

Table 4. Company Shares of Digestive Remedies: \% Value 2009-2013

\begin{tabular}{|c|c|c|c|c|c|}
\hline \% retail value rsp & 2009 & 2010 & 2011 & 2012 & 2013 \\
\hline Dabur India Ltd & 31.7 & 33.0 & 33.0 & 33.5 & 33.9 \\
\hline Abbott India Ltd & 13.5 & 13.1 & 13.1 & 13.1 & 13.2 \\
\hline GlaxoSmithKline Asia Pvt Ltd & 11.9 & 11.9 & 11.8 & 12.1 & 13.0 \\
\hline Pfizer Ltd & 8.6 & 8.9 & 9.8 & 10.1 & 10.5 \\
\hline TTK Healthcare Ltd & 5.7 & 5.5 & 5.3 & 5.2 & 5.2 \\
\hline Cadila Healthcare Ltd & 2.9 & 2.9 & 2.8 & 2.7 & 2.7 \\
\hline Piramal Healthcare Ltd & 1.8 & 1.8 & 1.7 & 1.6 & 1.6 \\
\hline
\end{tabular}

Source: Euromonitor International from official statistics, trade associations, trade press, company research, store checks, trade interviews, trade

The main drivers for the growth of this segment are a lack of clean drinking water and oily and spicy Indian food. Spices and oil are a major ingredient in almost all Indian cuisines and hence help in the growth of the market. Combined with a lack of hygiene, especially in semi-urban and rural areas, it provides a great opportunity for companies competing in this market. There has been a recent trend of urban Indians shifting their food habits and preferring non-oily and healthy food.

The highest growth in the digestives market was witnessed by antacids which grew at $9 \%$ and paediatric digestive formulation which grew by $6 \%$ in 2013. Indigestion and heartburn remedies continued to be the only OTC formulations which were driving this growth. Antacids contributed to $49 \%$ of the total value sales of digestive remedies market in the year thereby establishing its position as the key factor for growth in the segment ${ }^{3}$. Another reason

\footnotetext{
2 www.pwc.com/India, India Pharma Inc.: Capitalising on India's Growth Potential, CII Pharma Summit 2010, 22 Nov (1).pdf

${ }^{3}$ Sonam Jain, Reetesh Malvi, Jeetendra Kumar Purviya Concept of Self Medication: A Review, Int.Journal of Pharmaceutical \& Biological Archives IJPBA, May-June, 2011; Volume 2, Issue 3, 2(3): 831-836.
}

for the rapid growth of antacids was the fact that irrespective of a vegetarian or non-vegetarian diet, the Indian cuisine continued to be rich, oily and full of spices. Recommendations from family and friends and traditions were the important reasons that drove a potential consumer to buying a brand. Also, herbal remedies were preferred and desired much more over non-herbal formulations.

Table 5. Brand Shares of Digestive Remedies: \% Value 2010-2013

\begin{tabular}{|c|c|c|c|c|c|}
\hline $\begin{array}{c}\% \text { retail value } \\
\text { rsp }\end{array}$ & Company & 2010 & 2011 & 2012 & 2013 \\
\hline Hajmola & Dabur India Ltd & 23.4 & 23.4 & 23.7 & 24.4 \\
\hline Eno & $\begin{array}{c}\text { GlaxoSmithKline Asia } \\
\text { Pvt Ltd }\end{array}$ & 11.9 & 11.8 & 12.1 & 13.0 \\
\hline Digene & Abbott India Ltd & 10.6 & 10.6 & 10.6 & 10.7 \\
\hline Gelusil & Pfizer Ltd & 8.0 & 9.0 & 9.2 & 9.7 \\
\hline Pudin Hara & Dabur India Ltd & 7.3 & 7.3 & 7.5 & 7.0 \\
\hline $\begin{array}{c}\text { Woodward's } \\
\text { Celebrated } \\
\text { Gripe Water }\end{array}$ & TTK Healthcare Ltd & 5.5 & 5.3 & 5.2 & 5.2 \\
\hline Dulcolax & Cadila Healthcare Ltd & 2.9 & 2.8 & 2.7 & 2.7 \\
\hline Cremaffin & Abbott India Ltd & 2.1 & 2.1 & 2.1 & 2.1 \\
\hline Nature Care & Dabur India Ltd & 1.6 & 1.6 & 1.6 & 1.7 \\
\hline Polycrol Forte & Piramal Healthcare Ltd & 1.8 & 1.7 & 1.6 & 1.6 \\
\hline
\end{tabular}

Source: Euromonitor International from official statistics, trade associations, trade press, company research, store checks, trade interviews, trade sources

Table 6. Forecast Sales of Digestive Remedies by Category: \% Value Growth 2013-2018

\begin{tabular}{|c|c|c|}
\hline \% constant value growth & $\begin{array}{c}2013-18 \\
\text { CAGR }\end{array}$ & $\begin{array}{c}2013 / 18 \\
\text { TOTAL }\end{array}$ \\
\hline Paediatric Digestive Remedies & 0.6 & 3.1 \\
\hline Diarrhoeal Remedies & - & - \\
\hline IBS Treatments & - & - \\
\hline $\begin{array}{c}\text { Indigestion and Heartburn } \\
\text { Remedies }\end{array}$ & 3.7 & 20.0 \\
\hline Laxatives & 2.8 & 14.9 \\
\hline Motion Sickness Remedies & 1.6 & 8.3 \\
\hline Digestive Remedies & 3.2 & 17.3 \\
\hline
\end{tabular}

Source: Euromonitor International from trade associations, trade press, company research, trade interviews, trade sources

Digestive remedies will continue to be a major growth segment in the coming years owing to the inherent Indian habits which act as a stimulant for the necessity of these remedies. The perceivable threats for the growth of this segment are the shifting food habits of the urban consumers to a healthy diet and the very strong positioning of Dabur in the market. On the contrary, the semi-urban and rural Indian consumer represents an immense opportunity for growth in the market. 


\section{Sun Care}

Sun Care market in India is dominated by brands such as Hindustan Unilever, Lotus Herbal, Zydus Wellness. Where Hindustan Unilever, Cadila and Loreal are multinational brands, Indian brands have also emerged in the top ten such as Lotus herbals, VLCC and Amway. Sun care sector saw 16\% value growth to reach INR 2.2 Billion in last financial year 2012-2013. This growth has been fuelled by the growth in average unit price of these products which grows due to the introduction of innovative products such as gel-based sun screen and after-sun products. Consumers are attracted towards the product with higher SPF. Therefore, the manufacturers continuously bring in higher SPF categories. Hindustan Unilever Ltd leads with a value share of $32 \%$. Sun care is expected to see a value CAGR of $4 \%$ at constant 2013 prices to reach INR2.6 billion by $2018^{4}$. The same is represented below as per the forecasts by Euromonitor which depicts the percentage value of these products in mass marketing category vis-a-vis a premium category.

Table 7. Forecast Sales of Sun Care by Premium vs Mass: \% Value 2013-2018

\begin{tabular}{|c|c|c|c|c|c|c|}
\hline \% retail value rsp & 2013 & 2014 & 2015 & 2016 & 2017 & 2018 \\
\hline Premium & 6.2 & 6.2 & 6.2 & 6.2 & 6.2 & 6.3 \\
\hline Mass & 93.8 & 93.8 & 93.8 & 93.8 & 93.8 & 93.7 \\
\hline Total & 100.0 & 100.0 & 100.0 & 100.0 & 100.0 & 100.0 \\
\hline
\end{tabular}

Source: Euromonitor International from trade associations, trade press, company research, trade interviews, trade sources

Consumers of suncare products have primarily been women, especially in urban areas. Urban women consumers are generally well aware of the benefits of using sun protection. This increased awareness amongst women has been due to the aggressive promotional activities and efforts of manufacturers like Nivea India Pvt Ltd, Hindustan Unilever. Lately, a sunscreen with higher SPF was introduced by Lotus Herbals India Pvt Ltd attract consumers. Manufacturers also introduced oil-free formulas which helped them to achieve wider mass base amongst urban consumers. Along with oil-free formulas, gel based sunscreen has also gained popularity as it is less sticky and has a lighter texture. To increase their market shares, many manufacturers have developed gel based sunscreens with higher SPFs. One of the best examples of the same is introduction of Safe Sun UV Screen Matte Gel SPF 50 in 2013 which was targeted at people with oily or sensitive skin by Lotus Herbals.

Sun care manufacturers have always centred their marketing campaigns around women. More and more women have been able to buy the products due to rising disposable incomes and awareness, in spite of it being a high priced product. In 2013, mass brand Lakme leads the market, followed by Lotus Herbals and Everyuth. But there has been a marked decline in share of these products for Lakme and

\footnotetext{
${ }^{4}$ Euromonitor International from trade associations, trade press, company research, trade interviews, trade sources
}

increase in the sun care segment of Lotus Herbals as shown by the trends in figure below. Indian consumers still have preference for whitening creams which are supplemented by sun protection products to avoid tanning.

Table 8. Brand Shares of Sun Care: \% Value 2010-2013

\begin{tabular}{|c|c|c|c|c|c|}
\hline $\begin{array}{l}\% \text { retail value } \\
\text { rsp }\end{array}$ & Company & 2010 & 2011 & 2012 & 2013 \\
\hline Lakmé & $\begin{array}{l}\text { Hindustan Unilever } \\
\text { Ltd }\end{array}$ & 41.1 & 39.9 & 36.5 & 32.4 \\
\hline Lotus Herbals & Lotus Herbals Ltd & 19.5 & 20.0 & 20.6 & 21.3 \\
\hline Ever Yuth & Zydus Wellness Ltd & 10.3 & 10.5 & 9.5 & 9.4 \\
\hline VLCC & $\begin{array}{l}\text { VLCC Personal Care } \\
\text { Ltd }\end{array}$ & - & - & 6.1 & 7.5 \\
\hline $\begin{array}{l}\text { Garnier Skin } \\
\text { Naturals }\end{array}$ & L'Oréal India Pvt Ltd & 6.1 & 6.1 & 6.7 & 6.7 \\
\hline Attitude & $\begin{array}{c}\text { Amway India } \\
\text { Enterprises Pvt Ltd }\end{array}$ & 4.6 & 4.5 & 4.3 & 4.0 \\
\hline $\begin{array}{l}\text { Oriflame Sun } \\
\text { Care }\end{array}$ & Oriflame India Pvt Ltd & 3.3 & 1.9 & 2.1 & 3.0 \\
\hline Avon Sun & $\begin{array}{l}\text { Avon Beauty Products } \\
\text { India Pvt Ltd }\end{array}$ & 0.6 & 0.6 & 0.5 & 0.6 \\
\hline
\end{tabular}

Source: Euromonitor International from official statistics, trade associations, trade press, company research, store checks, trade interviews, trade sources

The OTC market in suncare segment has been dominated by international brands such as Hindustan Unilever Ltd. But 2013, saw emergence of domestic brands such as Lotus Herbals, Ayur, Himalaya and Shahnaz Husain. Most of these domestic brands use natural and herbal ingredients and therefore have gained popularity with women consumers. Amongst various brands, Hindustan Unilever Ltd under its brand Lakmé leads with a value share of $32 \%$ in 2013. Where Hindustan Unilever still dominated till 2013 with $32.4 \%$ value but overall there has been a steady decline since last few years. This decline seemed to have been captured by Lotus Herbals, whose suncare share has increased steadily to $21 \%{ }^{5}$. Lotus Herbals have been able to do this mainly by launching new products with higher SPF, by generating better brand recall and extending its distribution and marketing activities in South and West India to widen the consumer base.

Lotus Herbals Ltd recorded rapid value growth to reach a value share of $21 \%$ in 2013 . The increase was mainly due to the launch of many new products with higher SPFs which helped the company to generate brand recall amongst consumers. In addition, the company focused on extending its distribution to South and West India which helped it to expand its consumer base. 6

Sun protection is the only category as per past trends which has grown significantly mainly because of the wide availability of brands and increasing public awareness of the

\footnotetext{
5 Vijay Bhangale, OTC Marketing of Drugs, International Marketing Conference on Marketing \&Society, 8-10 April, 2007, IIMK, 397-402

${ }^{6}$ Nierop, Erjen and Fok, Dennis (2008), Interaction between shelf layout and marketing effectiveness and its impact on optimizing shelf arrangements
} 
dangerous effects of sun rays. In addition, increase in the number of promotional campaigns and new launches by manufacturers are likely to provide a further boost to sun care sales. Domestic manufacturers including Lotus Herbals Ltd will continue to strengthen their position in sun care. In addition, many international companies including Hindustan Unilever will focus on introducing products in new formats including gel based products over the forecast period.

Table 9. Company Shares of Sun Care: \% Value 2009-2013

\begin{tabular}{|c|c|c|c|c|c|}
\hline \% retail value rsp & 2009 & 2010 & 2011 & 2012 & 2013 \\
\hline Hindustan Unilever Ltd & 42.0 & 41.1 & 39.9 & 36.5 & 32.4 \\
\hline Lotus Herbals Ltd & 18.0 & 19.5 & 20.0 & 20.6 & 21.3 \\
\hline Zydus Wellness Ltd & 10.5 & 10.3 & 10.5 & 9.5 & 9.4 \\
\hline VLCC Personal Care Ltd & - & - & - & 6.1 & 7.5 \\
\hline L'Oréal India Pvt Ltd & 6.1 & 6.1 & 6.1 & 6.7 & 6.7 \\
\hline Amway India Enterprises Pvt Ltd & 4.5 & 4.6 & 4.5 & 4.3 & 4.0 \\
\hline Oriflame India Pvt Ltd & 2.5 & 3.3 & 1.9 & 2.1 & 3.0 \\
\hline $\begin{array}{c}\text { Avon Beauty Products India Pvt } \\
\text { Ltd }\end{array}$ & - & 0.6 & 0.6 & 0.5 & 0.6 \\
\hline
\end{tabular}

Source: Euromonitor International from official statistics, trade associations, trade press, company research, store checks, trade interviews, trade sources

\section{Future Scope}

In terms of the current market growth rate, Sun Care looks the most encouraging segment to venture into. The category has a plethora of whitening creams coming up which are doing well. These creams not only have to protect the skin from the harmful rays of the sun but also act as a moisturizer for the skin and lighten the skin tone. These are driving up the sales for this category and are being accepted by consumers in need for white and glowing skin in addition to its protection. Looking from the market value point, Analgesics is the category that should be ventured into as it already has a large consumer base to cater to and can hence accommodate a large number of players in the same segment. A concentration on herbal ingredients in the medication would give it an advantage and connect with the emotional angle of the consumers. Digestive remedies can be looked at as an immense opportunity segment which will always benefit from the rich Indian cuisine and the after effects of it. Lack of proper hygiene conditions will only help enhance the attractiveness of the category. The existing players are looking to add new variants and flavours to their existing portfolios to keep the product trendy as well as in sync with current times.

\section{Conclusion}

Prashant is left with exactly two weeks to decide upon which segment to enter. The decision has to be communicated to Rajeev in the board meeting to take place in Elimbic's Gurgaon headquarters. Rajeev expects the decision to be backed up by sound facts, figures and logic pertaining to current trends in the respective product categories by Prashant. This would justify the faith he has put in him by appointing him as the Marketing Director OTC. The Board of Directors has a keen eye on the forthcoming meeting as the decision would impact the future of Elimbi. A successful product launch could ensure that the OTC division is prioritized and looked upon as a driver for future growth. On the contrary, a failure could result in the closure of the division with the budget allocated to it being invested in some other division.

\section{REFERENCES}

[1] Ramaswamy Namakumari, Marketing management, Global Perspective Indian Context, 4th edition, pg-170.

[2] Gautam Kumra, Palash Mitra, Chandrika Pasricha (2005), India Pharma 2015: Unlocking the potential of the Indian Pharmaceutical Market, McKinsey \&Company.

[3] OPPI Organization of Pharmaceutical producers of India, 46th Annual Report 2011-2012.

[4] Gupta Supriya (2013), Emerging Indian OTC Markets, Apeejay - Journal of Management Sciences and Technology 1 (1), Oct - 2013, Noida, pg 24-29. 